\title{
Biosynthesis of xanthan gum from residual glycerin from biodiesel production for drilling fluids
}

\author{
Lillian B Brandão ${ }^{1}$, Jorge A Lopez ${ }^{2 *}$, Denilson J Assis ${ }^{1}$, Emiliano M Echevarria ${ }^{3}$, Janice I Druzian ${ }^{4}$ \\ From 5th Congress of the Brazilian Biotechnology Society (SBBIOTEC) \\ Florianópolis, Brazil. 10-14 November 2013
}

\begin{abstract}
Background
Several reports have focused on the value and biological transformation of industrial wastes as an alternative substrate for the production of high value-added components. In this context, it can cite the crude residual glycerin obtained as the primary byproduct of biodiesel production, which has increased exponentially during the last years. As an abundant residue, its disposal into the environment entails several drawbacks and health risks [1]. The bioconversion of this by-product into added-value products by fermentation processes is an important alternative to overcoming this environmental issue. Glycerin is an attractive feedstock for the production of useful chemicals [2], since the cost of the fermentation medium represents, for example, a critical aspect of the commercial production of xanthan, which is the most important microbial polysaccharide with widespread commercial applications (e.g. foodstuffs, pharmaceutical, agricultural products, petroliferous industries) [3], due to its rheological properties and its capacity to produce viscous solutions at low concentrations, together with other characteristics like its pseudoplastic property. This study investigates the effect of glycerin as alternative substrate for xanthan production by Xanthomonas campestris, by evaluating its operational production conditions as well as their physicochemical properties, aiming at its application as drilling fluid.
\end{abstract}

\section{Methods}

Assays were carried out in $250 \mathrm{~mL}$ shake flask cultures with $80 \mathrm{~mL}$ of medium containing $2 \%$ crude glycerin as an alternative substrate, supplemented with $0.01 \%$ urea and $0.1 \% \mathrm{KH}_{2} \mathrm{PO}_{4}$, compared with sucrose as control under the same operational conditions. In order to obtain the xanthan, the X. campestris mangiferaeindicae 2103

\footnotetext{
${ }^{2}$ Programa de Pós-Graduação em Biotecnologia Industrial, Universidade Tiradentes/Instituto de Tecnologia e Pesquisa, Aracaju, SE, Brazil Full list of author information is available at the end of the article
}

was incubated at $28^{\circ} \mathrm{C}$ in a rotary shaker at $250 \mathrm{~min}^{-1}$ for 120h. Samples were withdrawn at regular intervals and analyzed for concentrations of biomass, xanthan, residual substrate. The molecular weight of xanthan was estimated by size-exclusion chromatography. Its viscosity for drilling fluid was determined according to the Petrobrás $\mathrm{N}-2604$ standard [4]. Rheological data were fitted to the Ostwald-de-Waele model: $\mu=K(\gamma)^{n-1}$, using a regression analysis to ascertain the apparent viscosity $\left(K, n\right.$ and $\left.R^{2}\right)$.

\section{Results and conclusions}

The experimental results showed that glycerin supported xanthan production with a yield of $7.23 \mathrm{~g} \times \mathrm{L}^{-1}$, approximately $72 \%$ higher than that obtained using sucrose as carbon source. This biopolymer exhibited a consistency index $(K)$ of $6342.6 \pm 0,08 \mathrm{mPa} . \mathrm{s}^{\mathrm{n}}$ and flow rate $(n)$ of $0.2068 \pm$ 0,01 , according with the parameters established by the Petrobrás N-2604 standard [4], with a minimum $K$ of 1500 mPa. $\mathrm{s}^{\mathrm{n}}$ and maximum $n$ of 0.5 . These values were $70 \%$ and $30 \%$ higher, respectively, compared to gum from sucrose fermentation. Its molecular weight varied from 28.2 to 36.2 $\times 10^{6} \mathrm{Da}$, analogous value to those obtained from sucrose. Therefore, the results indicated that crude glycerin has the potential to be a cost-effective and promising alternative source of carbon for the production of non-food grade xanthan, whose rheological properties show a promising alternative use as a drilling fluid to enhance oil recovery [2,5], due to $K$ and $n$ satisfactory values.

\section{Acknowledgements \\ FAPESB and CNPq for financial support and fellowship, and Laboratory of Drilling Fluid, Carboflex Company for drilling fluids analysis.}

\section{Authors' details \\ 'Departamento de Engenharia Química, Escola Politécnica, Universidade Federal da Bahia, Salvador, BA, Brazil. ${ }^{2}$ Programa de Pós-Graduação em Biotecnologia Industrial, Universidade Tiradentes/Instituto de Tecnologia e Pesquisa, Aracaju, SE, Brazil. ${ }^{3}$ Laboratório Carboflex, Empresa Carboflex, Taquipe/São Sebastião do Passé, BA, Brazil. ${ }^{4}$ Departamento de Análises}


Published: 1 October 2014

\section{References}

1. Yang F, Hanna MA, Sun R: Value-added uses for crude glycerol - a byproduct of biodiesel production. Biotechnol Biofuels 2012, 5:13.

2. Silva GP, Mack M, Contiero J: Glycerol: a promising and abundant carbon source for industrial microbiology. Biotechnol Adv 2009, 27:30-39.

3. Palaniraj A, Jayaraman V: Production, recovery and applications of xanthan gum by Xanthomonas campestris. J Food Eng 2011, 106:1-12.

4. Viscosificante para fluidos usados na exploração e produção de poços de petróleo e gás. Especificação N-2604 2009, Petrobrás: Catálogo de normas técnicas Petrobrás.

5. Hamed SB, Belhadri M: Rheological properties of biopolymers drilling fluids. J Petrol Sci Eng 2009, 67:84-90.

doi:10.1186/1753-6561-8-S4-P187

Cite this article as: Brandão et al.: Biosynthesis of xanthan gum from residual glycerin from biodiesel production for drilling fluids. BMC Proceedings 2014 8(Suppl 4):P187.

\section{Submit your next manuscript to BioMed Central} and take full advantage of:

- Convenient online submission

- Thorough peer review

- No space constraints or color figure charges

- Immediate publication on acceptance

- Inclusion in PubMed, CAS, Scopus and Google Scholar

- Research which is freely available for redistribution

Submit your manuscript at www.biomedcentral.com/submit 